\title{
HOW TO CREATE SOCIAL SUPPORT ON FACEBOOK
}

\author{
I-Ping Chiang \\ National Taipei University \\ 151, University Rd., San Shia District, New Taipei City 23741, Taiwan \\ ipchiang@mail.ntpu.edu.tw \\ Yaw-Der Huang \\ National Taipei University \\ 151, University Rd., San Shia District, New Taipei City 23741, Taiwan \\ ddy119@gmail.com
}

\begin{abstract}
The growth of Facebook has accelerated with an increasing prevalence of social media. Facebook users have become more dependent on it by interacting with others. However, the precise means by which Facebook services deliver social support remains unclear. This study aims to investigate that Facebook exists as different types of social support within Facebook's various functions and communicative contexts. We employed the method of investigation on the internet to delivery questionnaires. Data are collected from a total of 1019 internet users, and we used research methods Chi-square test and MANOVA to examine that the Facebook usage behaviors of distinct demographic groups are significantly diverse. In the context of manipulated scenarios, tie strength and status lead to significantly distinct Facebook usage behaviors and produced dissimilar types and forms of social supports. As the result, in terms of social, esteem, companionship and information, supports were conveyed through like and comment functions, while emotional support was only conveyed through comment function.
\end{abstract}

Keywords: Facebook, Like Button, Status, Comments, Timeline, Social Support

\section{INTRODUCTION}

Facebook is a market leader in the recent boom of social media. By October 2012, Facebook usage data showed 1 billion monthly active members, 1.13 trillion likes, 140.3 billion friendships, 219 billion photos, 17 
billion geo-location tags, 22 billion music casts and 6 billion users who access Facebook through mobile devices ${ }^{1}$.

According to a survey form the Pew Internet \& American Life, more than half of teenagers consider that they have received consonance from social network. A study by Readwrite ${ }^{2}$ showed that the major driver for people to use Facebook is to satisfy their need to belong and requirements for self-expression. These two needs are related to the age, cultural background and personality of users. However, satisfying a need to belong through Facebook has not been explored by previous studies. Additionally, $\mathrm{Cobb}^{3}$ proposed that "social support is defined as information leading the subject to believe that he/she is cared for and loved, esteemed, and a member of a companionship of mutual obligations." This indicates that social support is potentially provided by Facebook. However, no findings of how the services of Facebook carry social supports, and how to harness increasing social supports on Facebook, have been reported to date.

The current research was conducted in order to elucidate the presence or lack of social supports through Facebook. Further investigations included determination of the type of social supports provided by Facebook and evaluation of whether diverse types of social supports were conveyed by several Facebook functions (e.g., like and comment). Furthermore, scenario manipulations were employed to unveil the factors of social support types. The current study intended to summarize the above analyses and draw a conclusion on the following topics:

- Potential social support types of Facebook inferred by published literatures.

- Differences in the uses of Facebook like buttons and comment boxes by Facebook users, using demographic variables as benchmarks.

- The types of social supports conveyed by Facebook like and comment functions and their differences.

- The difference between Facebook like and comment functions under several communicative contexts (e.g., profile picture, tie and status), the consequent types and the differences in potential social supports created by Facebook like and comment functions.

\section{RELATED WORK}

\subsection{Social Media}

Social media has become one of the major communication tools in the past decade. The network site in social media provides a platform for presentation of real-life friendship. Social media allows friends to actively 
communicate with each other. At the same time, social media permits users to semi-publically or publically disclose personal information and to browse personal information of other users to find people with similar interests $4,5,6$, 7,8

\subsection{Facebook}

Facebook is a social media website that has built its success on multiple factors, such as successful targeting of college students and provision of a large quantity of high quality information to users. The prerequisite of an e-mail address for signing up for a Facebook account improves the validity of shared personal information. Social media is similar to a community, but the majority of social media websites hold weaker designs for security, access control and privacy protection than Facebook. Unlike other social media websites, Facebook offers its members highly sophisticated privacy controls ${ }^{9}$. Additionally, Thompson ${ }^{10}$ showed that social media websites provide social and emotional supports, information resources and a tie to other people. Social media websites keep friends in contact and allow friends to develop advanced relationships through short status updates over a period of time. The intimacy of friendship improves as friends seek out common interests and share their experience of success and defeat. Hampton, Goulet, Marlow, and Rainie ${ }^{11}$ mentioned that social interaction on Facebook delivered high quality social supports and those who frequently update their status also receive more emotional support, such as assistance on personal issues.

\subsection{Like}

The like function offers a method to share information from a third party website on Facebook or to share information among members of a specific community. The like function helps generate traffic to the website of content provider. Consequently, a commercial use of a Facebook like is to track users and process their information. Facebook users add additional messages to web pages of interest and like a particular piece of content or photo tag. A like is given when the like function would signify to the other party that the mutual relationship is regarded as meaningful. Personal preferences of different things are made known to others through applications of the like to a specific picture, short video, advertisement or location $^{12}$.

\subsection{Comment}

The findings by Golder, Wilkinson, and Huberman $^{13}$ showed that well-maintained friendly relationships demand effort and investment. Leaving a comment on a Facebook timeline function allows Facebook users to earn social capital from friends located at great distance. Gilbert and 
Karahalios ${ }^{14}$ recognized that the degree of friendliness in a mutual relationship was predicted from the comments left on the walls of particular users. Oswald, Clark, and Kelly ${ }^{15}$ also indicated that information exchanged between friends and mutual communication reinforced friendships, which could be driven by rich content or positive self-exposure and positive support to others.

It is clear from the abovementioned literatures that people use social media to maintain and enhance social relationships, and simultaneously acquire social supports. However, previous literatures have not focused on the potential differences in Facebook usages of different demographics. Therefore, we propose the following hypotheses:

H1a: Males use Facebook like and comment functions more than females.

H1b: Younger age user groups use Facebook like and comment functions more than older user groups.

\subsection{Social Supports}

The Internet is a useful tool to build close relationships for individuals, and the primary value of the Internet to social supports is letting Internet users uphold relationships in a virtual community. Walther and Boyd ${ }^{16}$ proposed that the popularization of the Internet made numerous available computer-mediated environments, such as news discussion groups, e-mail mailing lists and real-time chat rooms for finding social support. The findings published by Liang, $\mathrm{Ho}, \mathrm{Li}$, and Turban ${ }^{17}$ showed that social media brings value to the social life of users. Several studies have compared the social connection between face-to-face and social media that Facebook provides an opportunity to develop and maintain social connectedness, which is associated with low depression and great satisfaction with life in the online environment ${ }^{5,18}$.

Several studies have found the Facebook brings us positive and negative effects that compare to general personal network characteristics. Park, Lee, and $\mathrm{Kim}^{6}$ have discussed that users possess a multitude of relationships to employ various types of Facebook usage, including leaving comment messages and posting photos to maintain their social interactions with friends. The users require different aspects of social connections and relationships to satisfy different communication needs and self-disclosure. Lewandowski et al. ${ }^{5}$ presented that the perceived amount of social support one receives affects its effectiveness. Walther and Parks ${ }^{19}$ mentioned that social supports on the Internet have changed conventional social supports in terms of communication channels and the interactive relationship between the demand and supply parties. The Internet provides not only 24-hour access to social supports that are not geographically restricted, but are also 
more comprehensive methods of social interaction. This infers that plenty of professionals are reached within the vague virtual communities.

Should enough time and attention be made, even weak ties with strangers were turned into intimate relationships. Sheldon ${ }^{20}$ and Bevan, Pfyl, and Barclay $^{21}$ have discussed a simple Facebook usage to explain self-disclosure. This work extends to consider the social supports issues to reflect the self-disclosure of Facebook users. Social supports refer to the experience of care, acknowledgement and help by an individual within a group. Within a community with good social supports, the community members are often willing to mutually interact with each other.

Taylor et al. ${ }^{22}$ revealed that social supports psychology literature emphasized two types of support: (1) provision of emotional support and a show of clear confidence in a person to help resolve or mitigate problems; and (2) information support includes provision of practical advice, recommendation and other information that help effectively resolve problems. Some scholars divided social supports into three categories, namely emotional, tangible and information supports ${ }^{22,23,24}$. Social support scale based on the functional connotation of social relationships was also developed. Such a scale categorized social supports into four types: (1) esteem support refers to the availability of a positive correspondence when comparing oneself to others; (2) belonging support to the availability of commonly interested parties to do things together; appraisal support to the availability of opportunity to discuss a problem with someone; and (4) tangible support to practical aid ${ }^{25,26,27}$. Additionally, other researchers proposed that social supports were categorized into five types (three types were psychological supports), namely (1) information support: message content that provides advice, suggestion, event relevant information, instant message and specific facts and solutions; (2) tangible support: message content which offers direct assistance, such as actual goods or services, to help someone release pressure; (3) esteem support: message content that delivers recognition, confirmation of the power or value sought by social supports and emphasizes the positive aspects of an event to reduce the remorse of a troubled person, and consequently grants positive feedback to individuals in need of social supports to instill confidence; (4) companionship support: message content that provides companionship, sense of connection and sense of belonging. Distressed individuals are told that there are others who faced similar situations. Companionship support is also referred to as social integration support, which gives individuals the sense of belonging to a particular group. Supported individuals accredited with a sense of belonging to a group participate in activities with other group members; and (5) emotional support: message content that offers love, compassion, listening, understanding, empathy, encouragement and 
care. Care and comfort are provided when needed to help individuals feel they are cared for. Subsequently, distressed individuals receive emotional comfort and encouragement ${ }^{28,29,30,31}$.

Social media platforms such as Facebook can also provide multiple types of social supports in computer-mediated environments. Therefore, the current study also aimed to verify the form through which Facebook carries different types of social supports by employing three different scenario manipulations (namely, profile picture, tie and status). We proposed the following hypotheses:

H2a: Between different profile pictures exists different Facebook behaviors (click a like button and leave a comment).

H2b: Between different tie strengths exists different Facebook behaviors (click a like button and leave a comment).

H2c: Between different connotations of status (positive or negative) exists different Facebook behaviors (click a like button and leave a comment).

H3a: Interesting profile pictures have more correlation between social supports than uninteresting profile pictures.

H3b: Strong ties have more correlation between social supports than weak ties.

H3c: Positive statuses have more correlations between social supports than negative statuses.

Even though numerous definitions of social support have been raised, there is a consensus among researchers that social supports are multi-faceted dimensions $^{29}$. The current study investigated the use of Facebook like and comment functions by users to show social supports, hence more refined descriptions of user psychology would reveal social supports that take place on Facebook. Therefore, the current study adopted the categorization by Cutrona and Russell ${ }^{29}$ and removed the tangible support that seldom occurs on the Internet. The current study divided social supports into four major types of social supports (namely, information, emotional, esteem and companionship supports) and explored three psychological supports (namely, esteem, emotional and companionship supports).

Hence, according to the abovementioned literature, the following hypotheses were proposed:

H4a: Interesting profile pictures receive larger numbers of types and forms of social supports than uninteresting profile pictures.

H4b: Strong ties receives a larger number of types and forms of social supports than weak ties. 
H4c: Positive statuses receive a larger number of types and forms of social supports than negative statuses.

Table 1. Social support literature

\begin{tabular}{cll}
\hline Social support & \multicolumn{1}{c}{ Definition } & Study \\
\hline Esteem Support & $\begin{array}{l}\text { Positive aspects of an event to reduce the remorse } \\
\text { of a troubled person, and consequently grant } \\
\text { positive feedback to individuals in need of social } \\
\text { supports to instill confidence into these } \\
\text { individuals. }\end{array}$ & $\begin{array}{l}\text { Cutrona \& Russell } \\
(1990) \\
\text { Taylor et al. (2004) } \\
\text { Fukkink (2011) }\end{array}$ \\
\hline $\begin{array}{c}\text { Companionship } \\
\text { Support }\end{array}$ & $\begin{array}{l}\text { Providing companionship, sense of connection } \\
\text { and sense of belonging through the message } \\
\text { content. }\end{array}$ & $\begin{array}{l}\text { Lewkowicz (2008) } \\
\text { Walther \& Parks } \\
(2002)\end{array}$ \\
\hline $\begin{array}{c}\text { Emotional Support understanding, empathy, encouragement and care } \\
\text { in time. }\end{array}$ & $\begin{array}{l}\text { Taylor et al. (2004) } \\
\text { Cutrona \& } \\
\text { Russell(1990) } \\
\text { Fukkink (2011) }\end{array}$ \\
\hline Support & $\begin{array}{l}\text { Providing practical advice, recommendations and } \\
\text { other information that help effectively resolve } \\
\text { problems. }\end{array}$ & $\begin{array}{l}\text { Taylor et al. (2004) } \\
\text { Fukkink (2011) }\end{array}$ \\
\hline
\end{tabular}

\section{MEASUREMENT}

This research used an online survey consisting of 38 questions to gather data, including eight questions to measure esteem, companionship, emotional and information supports; two questions to measure clicking like/comment functions on the content; and the remaining four questions to ensure that the respondent is a Facebook user. To ensure that the sampling conformed to real Internet users in Taiwan and to acquire more accurate information, the sampling ratio for Internet users was based on data from the Taiwan Network Information Center (TWNIC), the only official and non-profit organization offering Internet statistics in Taiwan. Our study employed age and gender quotas to match the demographics of recent Internet users provided by TWNIC.

In this study, the scales on which esteem, companionship, emotional and information supports were measured were modified from previous research $^{22,28,29,31}$. These supports were measured by a 6-point Likert scale, anchored with $1=$ "strongly disagree" and $6=$ "strongly agree," which was used in the questionnaire for all the items. The subjects were asked to indicate their tendency to agree with various statements.

We designed the questionnaire with several confirmation questions to prevent the respondents from behaving irresponsibly. That is to say, when target audiences may not take questionnaires seriously, he/she was screened out. This approach works and successfully avoids cognitive bias on the part 
of respondents. A total of 2,551 Internet users responded to this survey, but only 1,019 (39.94\%) respondents fully completed the questionnaire and were included in the data analysis. Of them, 538 (52.80\%) respondents were female and $481(47.20 \%)$ respondents were male. The ages of respondents ranged from 15-80, as shown in Table 2.

Table 2. Demographic data

\begin{tabular}{ccc}
\hline Gender & Count & Percentage \\
\hline Male & 481 & $47.2 \%$ \\
Female & 538 & $52.8 \%$ \\
Total & 1019 & $100.0 \%$ \\
\hline Age & Count & Percentage \\
\hline $15-19$ & 57 & $5.6 \%$ \\
$20-24$ & 151 & $14.8 \%$ \\
$25-29$ & 179 & $17.6 \%$ \\
$30-34$ & 220 & $21.6 \%$ \\
$35-39$ & 162 & $15.9 \%$ \\
$40-44$ & 105 & $10.3 \%$ \\
$45-49$ & 81 & $7.9 \%$ \\
$50-54$ & 27 & $2.6 \%$ \\
Above 55 & 37 & $3.6 \%$ \\
Total & 1019 & $100.0 \%$ \\
\hline
\end{tabular}

This work had collected 1,019 valid samples and set three control variables, including an interesting profile picture (beautiful women)/uninteresting profile picture, positive/negative status and strong/weak tie. The scenarios were split into eight groups (namely, 2 profile pictures $\times 2$ statuses $\times 2$ ties). The numbers of valid samples among the groups were approximate, as shown in Table 3.

This research used two questions to measure clicks on the like button and the content commenting habits. When a participant reads a given scenario, he/she was then asked to choose Yes or No in response to several questions. For example, "Will you click the like button when you see the above scenario?" The survey results are shown in Table 4.

This study measured four constructs of social supports; namely, esteem, companionship, emotional and information supports. Cronbach alphas were calculated in order to measure the reliability of these four constructs. The results of the empirical study revealed Cronbach alphas of $0.95,0.90,0.87$ and 0.94 for esteem, companionship, emotional and information supports, respectively. 
Table 3. The effective samples of each scenario

\begin{tabular}{lcc}
\hline Groups & Count & Percentage \\
\hline $\begin{array}{l}\text { Group (A). Photos of beautiful women, positive comment, } \\
\text { strong tie }\end{array}$ & 149 & $14.6 \%$ \\
$\begin{array}{l}\text { Group (B). Photos of beautiful women, positive comment, } \\
\text { weak tie }\end{array}$ & 123 & $12.1 \%$ \\
$\begin{array}{l}\text { Group (C). Photos of beautiful women, negative comment, } \\
\text { strong tie }\end{array}$ & 136 & $13.3 \%$ \\
Group (D). Photos of beautiful women, negative comment, & 121 & $11.9 \%$ \\
weak tie & 123 & $12.1 \%$ \\
Group (E). Uninteresting photos, positive comment, strong tie & 121 & $11.9 \%$ \\
Group (F). Uninteresting photos, positive comment, weak tie & 126 & $12.4 \%$ \\
Group (G). Uninteresting photos, negative comment, strong tie & 120 & $11.8 \%$ \\
Group (H). Uninteresting photos, negative comment, weak tie & 1019 & $100.0 \%$ \\
All Groups & & \\
\hline
\end{tabular}

Table 4. Facebook usage behaviors

\begin{tabular}{lcc}
\hline Usage Behavior & Count & Percentage \\
\hline Click like only & 134 & $13.2 \%$ \\
Leave a comment only & 218 & $21.4 \%$ \\
Both click like and leave a comment & 448 & $44.0 \%$ \\
Neither click like nor leave a comment & 219 & $21.5 \%$ \\
Total & 1019 & $100.0 \%$ \\
\hline
\end{tabular}

The composite reliability (CR) of these dimensions exceeded 0.8 , and the average variance extracted (AVE) for these dimensions exceeded 0.7, suggesting that the validity analysis result of this research met high standards, as shown in Table 5. All factor loadings, CR and AVE values exceeded the thresholds ${ }^{32}$.

Table 5. Reliability statistics of each scenario

\begin{tabular}{lccc}
\hline Groups & $\begin{array}{c}\text { Cronbach's } \\
\text { Alpha }\end{array}$ & $\begin{array}{c}\text { Composite } \\
\text { Reliability }\end{array}$ & AVE \\
\hline Esteem Support & 0.95 & 0.95 & 0.91 \\
Companionship Support & 0.90 & 0.90 & 0.82 \\
Emotional Support & 0.87 & 0.83 & 0.70 \\
Information Support & 0.94 & 0.94 & 0.89 \\
\hline
\end{tabular}

\section{RESULTS AND ANALYSIS}

Investigation into Facebook usage behaviors was performed using two questions to determine whether the study subjects will click like or leave a comment for the experimental scenarios. The study subjects were presented with four independent options of "click like only," "leave a comment only," 
"both click like and leave a comment," and "neither click like nor leave a comment." Furthermore, click like button and leave a comment were taken as nominal variables in a Chi-square test to unveil any significant difference in Facebook usage behaviors between several demographic variables (i.e., profile picture, tie, sentiment of status, gender, age and profession). A significance level of 0.05 was set $^{33}$. Additionally, test of standardized residuals was utilized to evaluate significant deviation of observed values from expected values ${ }^{15}$. An absolute value of standardized residual greater than 1.96 indicates that the observed value of a particular cell in a crosstab is significantly different from the expected value and infers statistical significance.

Table 6 and Table 7 show the crosstabs and Chi-square test results of the relationship of profile picture, tie, status, gender, age and profession of study subjects with various Facebook usage behaviors. In terms of Facebook usage behaviors (i.e., "click like only," "leave a comment only," "both click like and leave a comment," and "neither like nor leave a comment"), gender ratios showed significant differences $\left(\chi^{2}=9.15, d f=3, p<0.05\right)$ that observed that H1a was verified; distributions of age groups were significantly different $\left(\chi^{2}=43.52, d f=9, p<0.05\right)$, so H1b was verified; ratio of interesting profile picture was not significantly different from that uninteresting profile picture $\left(\chi^{2}=1.56, d f=3, p>0.05\right)$, so H2a was not verified; ratio of strong tie was significantly different from that of weak tie $\left(\chi^{2}=52.55, d f=3, p<0.05\right)$, so $\mathbf{H 2 b}$ was verified; and ratio of positive status was significantly different from the ratio of negative status $\left(\chi^{2}=\right.$ $14.04, d f=3, p<0.05$ ), so H2c was verified. These analytical data showed that, apart from profile picture, various Facebook usage behaviors were significantly diverse between different ties, statuses, genders, ages and professions at an overall level of significance. This indicated that Facebook usage behaviors were significantly diverse among manipulated ties and statuses and demographic variables, such as gender, age and profession. Hence, $\mathbf{H 1}$ was verified while $\mathbf{H} \mathbf{2}$ was partially verified.

Subsequent analyses of the standardized residual value of every cell shows that the study subjects (only click like) were those who held weaker ties (casual friends) and were mostly born post-1990; study subjects who only left a comment on Facebook were predominantly associated with strong ties (good friends), negative status and were born between 1970 and 1979; study subjects who both clicked like and left a comment mostly belonged to group associated with strong ties, positive status, male, born before 1969 and held secure employment; those study subjects who neither clicked like nor left a comment were typically associated with weak ties, of female gender, born between 1980 and 1989 and were prominently students. 
Table 6. Chi-squared test and test of standardized residuals

\begin{tabular}{|c|c|c|c|c|c|c|}
\hline \multirow{2}{*}{ Dependent variable } & \multicolumn{2}{|c|}{ Profile Picture } & \multicolumn{2}{|c|}{ Tie } & \multicolumn{2}{|c|}{ Status } \\
\hline & Interesting & Uninteresting & Strong & Weak & Negative & Positive \\
\hline Click like only & 62 & 72 & 93 & 41 & 59 & 75 \\
\hline Leave a comment only & 105 & 113 & 80 & 138 & 125 & 93 \\
\hline $\begin{array}{l}\text { Both click like and leave a } \\
\text { comment }\end{array}$ & 224 & 224 & 185 & 263 & 199 & 249 \\
\hline $\begin{array}{l}\text { Neither click like nor } \\
\text { leave a comment }\end{array}$ & 99 & 120 & 127 & 92 & 120 & 99 \\
\hline Total & 490 & 529 & 485 & 534 & 503 & 516 \\
\hline \multirow{3}{*}{$\begin{array}{ll}\text { Chi-Square } & \frac{\chi}{d f} \\
\text { Tests } & \begin{array}{l}\text { Asympto } \\
\text { significan }\end{array} \\
& (P) \\
\end{array}$} & \multicolumn{2}{|c|}{1.56} & \multicolumn{2}{|c|}{52.55} & \multicolumn{2}{|c|}{14.04} \\
\hline & \multicolumn{2}{|r|}{3} & \multicolumn{2}{|c|}{3} & \multicolumn{2}{|c|}{3} \\
\hline & \multicolumn{2}{|c|}{0.67} & \multicolumn{2}{|c|}{0} & \multicolumn{2}{|c|}{0} \\
\hline
\end{tabular}

Table 7. Chi-squared test and test of standardized residuals (continue)

\begin{tabular}{|c|c|c|c|c|c|c|}
\hline \multirow[b]{2}{*}{ Dependent variable } & \multicolumn{2}{|c|}{ Gender } & \multicolumn{4}{|c|}{ Age } \\
\hline & Male & Female & $\begin{array}{l}\text { Born } \\
\text { post } \\
1990\end{array}$ & $\begin{array}{c}\text { Born } \\
\text { between } \\
1980 \text { and } \\
1989\end{array}$ & $\begin{array}{c}\text { Born } \\
\text { between } \\
1970 \text { and } \\
1979\end{array}$ & $\begin{array}{c}\text { Born } \\
\text { before } \\
1969\end{array}$ \\
\hline Click like only & 64 & 70 & 27 & 49 & 34 & 24 \\
\hline Leave a comment only & 98 & 120 & 24 & 85 & 83 & 26 \\
\hline Both click like and leave a comment & 232 & 216 & 46 & 151 & 152 & 99 \\
\hline $\begin{array}{l}\text { Neither click like nor leave a } \\
\text { comment }\end{array}$ & 87 & 132 & 36 & 107 & 47 & 29 \\
\hline Total & 481 & 538 & 133 & 392 & 316 & 178 \\
\hline$\chi^{2}$ & \multicolumn{2}{|c|}{9.15} & \multicolumn{4}{|c|}{43.52} \\
\hline Chi-Square $\frac{\pi}{d f}$ & \multicolumn{2}{|c|}{3} & \multicolumn{4}{|c|}{9} \\
\hline $\begin{array}{ll}\text { Tests } & \begin{array}{l}\text { Asymptotic } \\
\text { significance }(P)\end{array}\end{array}$ & \multicolumn{2}{|c|}{0.03} & \multicolumn{4}{|c|}{0} \\
\hline
\end{tabular}

To further analyze whether the types of social supports acquired from scenario manipulation were significantly different, multivariate analysis of variance (MANOVA) was conducted using manipulated scenarios and the dimensions of social supports. The current study incorporated two types of Facebook usage behaviors (both click like button and leave a comment), and four types of social supports (esteem, companionship, emotional and information). Therefore, eight (namely, 2 Facebook usage behaviors $\times 4$ social supports) dependent variables of social supports were devised to represent the social supports conveyed through different behaviors. Three scenarios (i.e., profile picture, tie and status) were considered as independent variables. Eight scenarios were independent samples (namely, 2 
profile pictures $\times 2$ ties $\times 2$ statuses, as shown in the "Value Label" column in Table 5). Strength of ties and the sentiment of statuses were found to be significantly different $(p<0.05)$ in different behaviors by MANOVA, so H3b and H3c were verified; interactions of profile pictures with other variables were not significantly different $(p>0.05)$, so H3c and H4a were not verified. Therefore, $\mathbf{H 3}$ was partially verified, as shown in Tables 8 and 9.

Table 8. Between-subjects factors

\begin{tabular}{lcc}
\hline & Value Label & $\mathrm{N}$ \\
\hline \multirow{2}{*}{ Profile Picture } & $\begin{array}{c}\text { Interesting profile picture } \\
\text { Uninteresting profile } \\
\text { picture }\end{array}$ & 490 \\
\multirow{2}{*}{ Tie } & Weak tie & 529 \\
\hline \multirow{2}{*}{ Status } & Strong tie & 485 \\
& Negative status & 534 \\
\hline
\end{tabular}

Table 9. Multivariate tests

\begin{tabular}{lccccc}
\hline \multirow{2}{*}{ Effect } & $\Lambda$ & $F$ & Hypothesis & Error & Significance \\
& & & $d f$ & $d f$ & $(P)$ \\
\hline Profile Picture & 0.01 & 0.65 & 8 & 1004 & 0.74 \\
Tie & 0.07 & 8.80 & 8 & 1004 & 0 \\
Status & 0.09 & 12.32 & 8 & 1004 & 0 \\
Profile Picture * Tie & 0.01 & 0.83 & 8 & 1004 & 0.58 \\
Profile Picture * Status & 0.04 & 1.72 & 8 & 1004 & 0.09 \\
Tie * Status & 0.01 & 0.96 & 8 & 1004 & 0.46 \\
Profile Picture * Tie * Status & 0.004 & 0.48 & 8 & 1004 & 0.87 \\
\hline Note:
\end{tabular}

Note: the symbol * means correlation.

The results of MANOVA show that the types of social supports exerted by tie and status were significantly different. Results from tests of between-subjects effects further revealed that manipulations of tie and status lead to different social supports. Esteem, companionship, emotional and information supports in comment form are attained through tie manipulations. Manipulation of status harnesses esteem, companionship and information supports in the form of "Like", as shown in Table 10. 
Table 10. Tests of between-subjects effects

\begin{tabular}{|c|c|c|c|c|c|c|c|}
\hline Scenario & $\begin{array}{l}\text { Independent } \\
\text { Variable }\end{array}$ & $\begin{array}{l}\text { Dependent } \\
\text { Variable }\end{array}$ & $\begin{array}{l}\text { Type III } \\
\text { Sum of } \\
\text { Squares }\end{array}$ & $d f$ & $\begin{array}{l}\text { Mean } \\
\text { Square }\end{array}$ & $F$ & $\begin{array}{c}\text { Significance } \\
(P)\end{array}$ \\
\hline \multirow{8}{*}{ Tie } & \multirow{5}{*}{ Like -> } & Esteem Support & 1.33 & 1 & 1.33 & 0.24 & 0.63 \\
\hline & & $\begin{array}{l}\text { Companionship } \\
\text { Support }\end{array}$ & 2.17 & 1 & 2.17 & 0.44 & 0.51 \\
\hline & & Emotional Support & 0.62 & 1 & 0.62 & 0.12 & 0.73 \\
\hline & & $\begin{array}{l}\text { Information } \\
\text { Support }\end{array}$ & 0.81 & 1 & 0.81 & 0.17 & 0.68 \\
\hline & & Esteem Support & 243.97 & 1 & 243.97 & 51.1 & $\mathbf{0}$ \\
\hline & \multirow{3}{*}{ Comment -> } & $\begin{array}{c}\text { Companionship } \\
\text { Support }\end{array}$ & 249.52 & 1 & 249.52 & 54.71 & $\mathbf{0}$ \\
\hline & & $\begin{array}{c}\text { Emotional } \\
\text { Support }\end{array}$ & 255.56 & 1 & 255.56 & 52.70 & $\mathbf{0}$ \\
\hline & & $\begin{array}{c}\text { Information } \\
\text { Support }\end{array}$ & 296.25 & 1 & 296.25 & 59.73 & $\mathbf{0}$ \\
\hline \multirow{8}{*}{ Status } & \multirow{3}{*}{ Like -> } & Esteem Support & 63.10 & 1 & 63.10 & 11.38 & 0.001 \\
\hline & & $\begin{array}{c}\text { Companionship } \\
\text { Support }\end{array}$ & 68.62 & 1 & 68.62 & 13.90 & $\mathbf{0}$ \\
\hline & & $\begin{array}{c}\text { Emotional } \\
\text { Support }\end{array}$ & 24.10 & 1 & 24.10 & 4.53 & 0.03 \\
\hline & \multirow{5}{*}{ Comment -> } & $\begin{array}{c}\text { Information } \\
\text { Support }\end{array}$ & 58.06 & 1 & 58.06 & 12.26 & $\mathbf{0}$ \\
\hline & & Esteem Support & 2.42 & 1 & 2.42 & 0.51 & 0.48 \\
\hline & & $\begin{array}{l}\text { Companionship } \\
\text { Support }\end{array}$ & 1.76 & 1 & 1.76 & 0.39 & 0.54 \\
\hline & & Emotional Support & 2.44 & 1 & 2.44 & 0.5 & 0.48 \\
\hline & & $\begin{array}{l}\text { Information } \\
\text { Support }\end{array}$ & 7.33 & 1 & 7.33 & 1.48 & 0.22 \\
\hline
\end{tabular}

Estimated marginal means were subsequently employed by the current research to elucidate how scenarios (e.g., tie and status) influence social supports. As shown in Table 11, neither the upper nor the lower bounds of strong and weak ties overlapped, and the mean value of strong tie was higher than that of weak tie. This indicated that strong tie indeed lead to acquisition of more esteem, companionship, emotional and information supports in comments, so H4b was verified; similarly, positive status brings about more esteem, companionship and information supports in "Like," so H4c was verified; consequently, $\mathbf{H 4}$ was partially verified. 
Table 11. Estimated marginal means

\begin{tabular}{|c|c|c|c|c|c|c|c|}
\hline \multirow{3}{*}{ Scenario } & \multirow{3}{*}{$\begin{array}{l}\text { Independent } \\
\text { Variable }\end{array}$} & \multirow{3}{*}{$\begin{array}{l}\text { Dependent } \\
\text { Variable }\end{array}$} & & \multirow{3}{*}{ Mean } & \multirow{3}{*}{$\begin{array}{l}\text { Std. } \\
\text { Error }\end{array}$} & \multicolumn{2}{|c|}{$\begin{array}{l}\text { 95\% Confidence } \\
\text { Interval }\end{array}$} \\
\hline & & & & & & Lower & Upper \\
\hline & & & & & & Bound & Bound \\
\hline \multirow{8}{*}{ Tie } & \multirow{4}{*}{ Comment-> } & \multirow{2}{*}{ Esteem Support } & Strong Tie & 3.34 & 0.1 & 3.16 & 3.53 \\
\hline & & & Weak Tie & 2.36 & 0.1 & 2.17 & 2.56 \\
\hline & & Companionship & Strong Tie & 3.3 & 0.09 & 3.11 & 3.48 \\
\hline & & Support & Weak Tie & 2.3 & 0.1 & 2.11 & 2.49 \\
\hline & \multirow{4}{*}{ Comment-> } & Emotional & Strong Tie & 3.41 & 0.1 & 3.22 & 3.6 \\
\hline & & Support & Weak Tie & 2.41 & 0.1 & 2.21 & 2.6 \\
\hline & & Information & Strong Tie & 3.49 & 0.1 & 3.3 & 3.68 \\
\hline & & Support & Weak Tie & 2.41 & 0.1 & 2.21 & 2.61 \\
\hline \multirow{6}{*}{ Status } & \multirow{2}{*}{ Like-> } & \multirow{2}{*}{ Esteem Support } & $\begin{array}{l}\text { Positive } \\
\text { Status }\end{array}$ & 2.88 & 0.1 & 2.67 & 3.08 \\
\hline & & & $\begin{array}{l}\text { Negative } \\
\text { Status }\end{array}$ & 2.38 & 0.11 & 2.17 & 2.58 \\
\hline & \multirow{2}{*}{$->$} & \multirow{2}{*}{$\begin{array}{l}\text { Companionship } \\
\text { Support }\end{array}$} & $\begin{array}{l}\text { Positive } \\
\text { Status }\end{array}$ & 2.7 & 0.1 & 2.51 & 2.89 \\
\hline & & & $\begin{array}{l}\text { Negative } \\
\text { Status }\end{array}$ & 2.18 & 0.1 & 1.99 & 2.37 \\
\hline & \multirow{2}{*}{ Like-> } & \multirow{2}{*}{$\begin{array}{l}\text { Information } \\
\text { Support }\end{array}$} & $\begin{array}{l}\text { Positive } \\
\text { Status }\end{array}$ & 2.58 & 0.1 & 2.4 & 2.77 \\
\hline & & & $\begin{array}{l}\text { Negative } \\
\text { Status }\end{array}$ & 2.11 & 0.1 & 1.91 & 2.3 \\
\hline
\end{tabular}

\section{CONCLUSIONS AND SUGGESTIONS}

This study summarized the Facebook like and comment functions and several types of social supports applicable to Facebook from the literature. Survey was conducted using quota designed according to Internet user demographics, and reliability and validity analyses were performed to ensure the validity of the chosen samples. Conclusions on the influence of scenarios and demographics were drawn for two distinct aspects.

Different demographics and scenario manipulations lead to various Facebook behaviors: in terms of the association of tie with Facebook behaviors, weak ties were prominently linked to the behaviors of "click like only" and "neither click like nor leave a comment," while strong ties were more significantly associated with behaviors of "leave a comment only" and "both click like and leave a comment"; in terms of the association of status with Facebook behaviors, negative status was found to be prevalent in "leave comment only" events, while presence of positive status is strong in behavior of "both click like and leave a comment"; in the relationship between gender and Facebook behavior, males were strongly associated with "click like and leave a comment" while a higher ratio of females would 
"neither click like nor leave a comment"; in terms of age, those users who were born post-1990 prominently showed "click like only" behavior, those born between 1980 and 1989 dominated the "neither click like nor leave a comment" behavior, those born between 1970 and 1979 were highly associated with "leave a comment only" and those born before 1969 showed strong association with "both click like and leave a comment." In terms of professions, students were strongly associated with "neither click like nor leave a comment" and users with secure employment were more prominently presented in "both click like and leave a comment" events. One reason is that the older people have few friends, but their relationships are close such that any message left has a high probability of receiving a reply to convey social support. On the contrary, young people have a large amount of friends, but the relationships are not as close, which results in fewer conveyances.

Strength of tie and sentiment of status received different types of social supports in various forms: strong ties receive various types of social supports in the form of comments, while positive status attains esteem, companionship and information supports in the form of like function. Additionally, profile pictures do not influence social supports, but numerous popular fan groups tried manipulating profile pictures to harness more likes and comments. This study proposes that profile picture exerts influence toward attractiveness, not social support, because a profile picture resembles the identity of a person or brand on Facebook. This topic may be distal to the theme of this work, but it is nevertheless an interesting issue worthy of further investigation.

The findings from this study prove useful as a reference standard for marketing professionals involved in the management of fan groups on Facebook. The Facebook usage preferences of several demographics and the results of scenario manipulations confirmed that positive and negative statuses indeed influence the behaviors of the audiences; it is similarly extrapolated that exploiting diverse forms of status (through additional attachments of photos, presentation methods or contextual perspectives) lead to improved marketing effectiveness. The core of social media is the quality of social interaction. The current study verified that the like and comment functions on Facebook act as a bridge for conveying social supports, and further analyses revealed that the strength of tie and sentiment of status produce several types of social supports through different forms. Specifically, esteem, companionship and information supports are mediated through likes and comments. It inferred that the meaning of a like button click, which is a multi-faceted concept, is similar to that of social supports; emotional support is conveyed through leaving a comment, which means compassion, comfort and care are better expressed through text. 
Because the current study only analyzed the social supports provided by Facebook like and comment functions, a comprehensive understanding was not drawn for the types of social supports conveyed by the functions of Facebook. Despite the combinations of scenario manipulations with likes and comments, it provided hints into the potential influences of Facebook functions, it recommends that the subsequent research should incorporate with more services of Facebook as research variables (such as the poke, tag, event invitation and chat room functions) or employ several control variables (such as status updates with attaching photos and check-in messages with text) attached to ensure a holistic picture is completed. Furthermore, future study also considers study subjects of various countries or personalities. All subjects of the current study were Taiwanese. Revelation of differences between cultures and personalities will add to more comprehensive perspectives and discoveries.

\section{REFERENCES}

[1] WSJ, Facebook: One billion and counting. Retrieved on January 16, 2013, from http://online.wsj.com/article/SB1000087239639044363540457803616 4027386112.html?mod=e2fb.

[2] Readwrite, Study: Why do people use facebook? Retrieved on January 16, 2013, from http://readwrite.com/2012/01/16/study_why_do_people_use_facebook.

[3] M. Madden, A. Lenhart, S. Cortesi, U. Gasser, M. Duggan, A. Smith and M. Beaton, Teens, social media, and privacy. Retrieved on March 22, 2015, from http://www.pewinternet.org/2013/05/21/teens-social-media-and-privac $\mathrm{y} / \mathrm{s}$

[4] S. Cobb, Presidential Address-1976.Social support as a moderator of life stress. Psychosomatic medicine, 38(5), p300-314, 1976.

[5] M. Burke, C. Marlow, and T. Lento, Social network activity and social well-being. Paper presented at the 28th international conference on Human Factors in Computing Systems, Atlanta, GA, USA, April 10-15, 2010. http://dx.doi.org/10.1145/1753326.1753613.

[6] J. Lewandowski, D.R. Benjamin, M.J. Parks, and J.T. Siegel, The effect of informal social support: Face-to-face versus computer-mediated communication. Computers in Human Behavior, 27(5), p1806-1814, 2011. http://dx.doi.org/10.1016/j.chb.2011.03.008.

[7] N. Park, S. Lee, and J.H. Kim, Individuals' personal network characteristics and patterns of Facebook use: A social network approach. Computers in Human Behavior, 28(5), p1700-1707, 2012. http://dx.doi.org/10.1016/j.chb.2012.04.009. 
[8] C. Ross, E.S. Orr, M. Sisic, J.M. Arseneault, M.G. Simmering, and R. R. Orr, Personality and motivations associated with Facebook use. Computers in Human Behavior, 25(2), p578-586, 2009. http://dx.doi.org/10.1016/j.chb.2008.12.024.

[9] K. Subrahmanyam, S.M. Reich, N. Waechter and G. Espinoza, Online and offline social networks: Use of social networking sites by emerging adults. Journal of Applied Developmental Psychology, 29(6), p420-433, 2008. http://dx.doi.org/10.1016/j.appdev.2008.07.003.

[10] A. Acquisti, and R. Gross, Imagined communities: Awareness, information sharing, and privacy on the Facebook. Privacy Enhancing Technologies: Lecture Notes in Computer Science, 4258, p36-58, 2006. http://dx.doi.org/10.1007/11957454_3.

[11] C. Thompson, Brave new world of digital intimacy. New York Times, September 7, 2008.

[12] K.N. Hampton, L.S. Goulet, C. Marlow, and L. Rainie, Why most Facebook users get more than they give. Pew Internet Report, 2012. Retrieved on March 22, 2015, from http://www.pewinternet.org/2012/02/03/why-most-facebook-users-getmore-than-they-give/.

[13] A. Roosendaal, Facebook tracks and traces everyone: Like this! Tilburg Law School Research Paper, 2011.

[14] S.A. Golder, D.M. Wilkinson, and B.A. Huberman, Rhythms of social interaction: Messaging within a massive online network. Communities and Technologies, p41-66, 2007. http://dx.doi.org/10.1007/978-1-84628-905-7_3.

[15] E. Gilbert, and K. Karahalios, Predicting tie strength with social media. Paper presented at the 27th international conference on Human Factors in Computing Systems, Boston, MA, USA, April 4-9, 2009. http://dx.doi.org/10.1145/1518701.1518736.

[16] D.L. Oswald, E.M. Clark, and C.M. Kelly, Friendship maintenance: An analysis of individual and dyad behaviors. Journal of Social and Clinical Psychology, 23(3), p413-441, 2004. http://dx.doi.org/10.1521/jscp.23.3.413.35460.

[17] J.B. Walther, and S. Boyd, Attraction to computer-mediated social support. In C.A. Lin and D. Atkin (Eds.), Communication technology and society: Audience adoption and uses (p153-188). Cresskill, NJ: Hampton Press, 2002.

[18] T.P. Liang, Y.T. Ho, Y.W. Li, and E. Turban, What drives social commerce: The role of social support and relationship quality. International Journal of Electronic Commerce, 16(2), p69-90, 2011. http://dx.doi.org/10.2753/JEC1086-4415160204.

[19] R. Grieve, M. Indian, K. Witteveen, G.A. Tolan, and J. Marrington, Face-to-face or Facebook: Can social connectedness be derived online? 
Computers in Human Behavior, 29(3), p604-609, 2013. http://dx.doi.org/10.1016/j.chb.2012.11.017.

[20] J.B. Walther, and M.R. Parks, Cues filtered out, cues filtered in: Computer-mediated communication and relationships. In M.L. Knapp and J.A. Daly (Eds.), Handbook of Interpersonal Communication (3rd ed.) (p529-563). Thousand Oaks, CA: Sage.

[21] P. Sheldon, Voices that cannot be heard: Can shyness explain how we communicate on Facebook versus face-to-face? Computers in Human Behavior, 29(4), p1402-1407, 2013. http://dx.doi.org/10.1016/j.chb.2013.01.016.

[22] J. L. Bevan, J. Pfyl, and B. Barclay, Negative emotional and cognitive responses to being unfriended on Facebook: An exploratory study. Computers in Human Behavior, 28(4), p1458-1464, 2012. http://dx.doi.org/10.1016/j.chb.2012.03.008.

[23] S. E. Taylor, D. K. Sherman, H. S. Kim, J. Jarcho, K. Takagi, and M. S. Dunagan, Culture and social support: Who seeks it and why? Journal of Personality and Social Psychology, 87(3), p354-362, 2004. http://dx.doi.org/10.1037/0022-3514.87.3.354.

[24] M. Lewkowicz, M. Marcoccia, H. Atifi, A. Benel, G. Gaglio, N. Gauducheau, and M. Tixier, Online social support: Benefits of an interdisciplinary approach for studying and designing cooperative computer-mediated solutions. In P. Hassanaly, A. Ramrajsingh, D. Randall, P. Salembier, and M. Tixier (Eds.), Proceedings of the 8th Conference on the Design of Cooperative Systems (p144-155). Carry-le-Rouet, Provence, France: Université de Technologie de Troyes, 2008.

[25] S.A. Shumaker, and A. Brownell, Toward a theory of social support: Closing conceptual gaps. Journal of social issues, 40(4), p11-36, 1984. http://dx.doi.org/10.1111/j.1540-4560.1984.tb01105.x

[26] H. Ali, Exchanging value within individuals' networks: Social support implications for health marketers. Journal of Marketing Management, 27(3-4), p316-335,

2011. http://dx.doi.org/10.1080/0267257X.2011.547075.

[27] S. Cohen, and H.M. Hoberman, Positive events and social supports as buffers of life change stress. Journal of Applied Social Psychology, 13(2), p99-125,

1983. http://dx.doi.org/10.1111/j.1559-1816.1983.tb02325.x.

[28] S. Cohen, R. Mermelstein, T. Kamarck, and H. Hoberman, Measuring the functional components of social support. Social support: Theory, research and applications, 24, p73-94, 1985. http://dx.doi.org/10.1007/978-94-009-5115-0_5.

[29] S. Ashley, Exploring facebook as an online support group for smoking cessation. Colorado State University, 2012. 
[30] C.E. Cutrona, and D.W. Russell, Type of social support and specific stress: Toward a theory of optimal matching. In B.R. Sarason, I.G. Sarason, and G.R. Pierce (Eds.), Social support: An interactional view (p319-366). New York: Wiley, 1990.

[31] R. Fukkink, Peer counseling in an online chat service: A content analysis of social support. Cyberpsychology, Behavior, and Social Networking, 14(4), p247-251, 2011. http://dx.doi.org/10.1089/cyber.2010.0163.

[32] H.C. Ko, L.L. Wang, and Y.T. Xu, What kinds of social support does the audience offer to a-list journal-type bloggers? Paper presented at the Pacific Asia Conference on Information Systems conference, Brisbane, Australia, July 7-11, 2011.

[33] C. Fornell, and D. Larcker, A second generation of multivariate analysis: Classification of methods and implications for marketing research. University of Michigan, 1985. 
